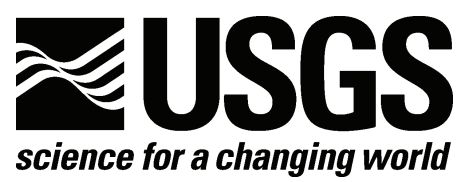

\title{
Major and EDXRF trace element chemical analyses of volcanic rocks from Lassen Volcanic National Park and vicinity, California
}

By Michael A. Clynne, L.J.P. Muffler, D.F. Siems*, J.E. Taggart Jr., and Peggy Bruggman

2008

*Deceased

Open-File Report 2008-1091

U.S. Department of the Interior

U.S. Geological Survey 


\title{
U.S. Department of the Interior DIRK KEMPTHORNE, Secretary
}

\author{
U.S. Geological Survey \\ Mark D. Myers, Director
}

U.S. Geological Survey, Reston, Virginia 2008

For product and ordering information:

World Wide Web: http://www.usgs.gov/pubprod

Telephone: 1-888-ASK-USGS

For more information on the USGS - the Federal source for science about the Earth, its natural and living resources, natural hazards, and the environment:

World Wide Web: http://www.usgs.gov

Telephone: 1-888-ASK-USGS

Suggested citation:

Clynne, M.A., Muffler, L.J.P., Siems, D.F., Taggart, J.E. Jr., and Bruggman, Peggy, 2008, Major and EDXRF trace element chemical analyses of volcanic rocks from Lassen Volcanic National Park and vicinity: U.S. Geological Survey Open-File Report 2008-1091, 10 p. and .xls table [http://pubs.usgs.gov/of/2008/1091/].

Any use of trade, product, or firm names is for descriptive purposes only and does not imply endorsement by the U.S. Government.

Although this report is in the public domain, permission must be secured from the individual copyright owners to reproduce any copyrighted material contained within this report. 


\section{Contents}

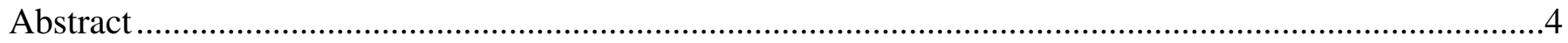

Introduction ....

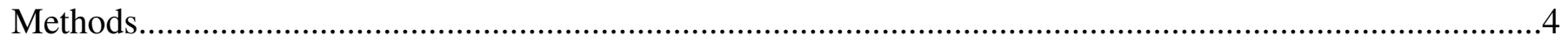

Location and Attribution of the Samples, Data Processing, and Presentation................................................6

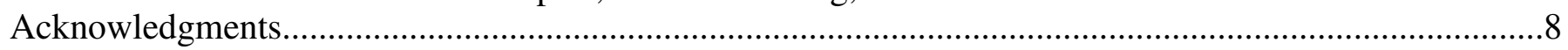

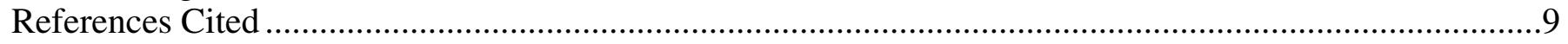

\section{Figure}

1. Map showing area of geologic map (Clynne and Muffler, in press), topographic quadrangles, and major volcanic features.

\section{Table}

1. Chemical analyses of rocks. http://pubs.usgs.gov/of/2008/1091/of2008-1091_table1.xls 


\section{Abstract}

This open-file report presents WDXRF major-element chemical data for late Pliocene to Holocene volcanic rocks collected from Lassen Volcanic National Park and vicinity, California. Data for $\mathrm{Rb}, \mathrm{Sr}, \mathrm{Ba}, \mathrm{Y}, \mathrm{Zr}, \mathrm{Nb}, \mathrm{Ni}, \mathrm{Cr}, \mathrm{Zn}$ and $\mathrm{Cu}$ obtained by EDXRF are included for many samples. Data are presented in an EXCEL spreadsheet and are keyed to rock units as displayed on the Geologic Map of Lassen Volcanic National Park and vicinity (Clynne and Muffler, in press). Location of the samples is given in latitude and longitude in degrees and decimal minutes and in decimal degrees.

\section{Introduction}

This open-file report presents major element chemical data for late Pliocene to Holocene volcanic rocks collected during geologic mapping of Lassen Volcanic National Park and vicinity, California (figure 1). Most samples were colleceted in the area bounded by $40^{\circ} 20^{\prime}, 40^{\circ} 40^{\prime}$ and $\left.121^{\circ} 7.5^{\prime}, 121^{\circ} 45^{\prime}\right)$. A few of the samples were collected from slightly beyond the area of the geologic map and are included here when required to characterize a map unit. An exception to this generality is that a number of samples of Maidu Volcanic Center rocks from south of the map area are included in order to augment the Maidu Volcanic Center data set. Samples collected in conjunction with thesis projects (Borg, 1989; Lerch, 1987) and geochemical studies (Feeley and others, in press) that were analyzed by the USGS are included. Some of the data presented herein were previously published (Borg, 1989; Clynne, 1984; Bullen and Clynne, 1990; Clynne, 1993; Clynne, 1999; Lerch, 1987; Muffler and others, 1994). Additional compositional and isotopic data for some samples can be found in Bacon and others, (1997); Borg (1989); Borg (1995); Borg and Clynne (1998); Borg and others (1997); Borg and others (2000); Borg and others (2002); Clynne (1990); Feeley and others (in press); Rose and others (1994); and Trimble and others, (1984).

\section{Methods}

Samples were ground in an aluminum oxide shatter box. Bulk-rock major-element compositions were determined at the USGS Analytical Laboratory in Lakewood, Colorado by wavelength-dispersive X-ray fluorescence analysis of pressed powder pellets (Taggart and others, 1987). Trace elements were determined by Peggy Bruggman at Menlo Park by energy 


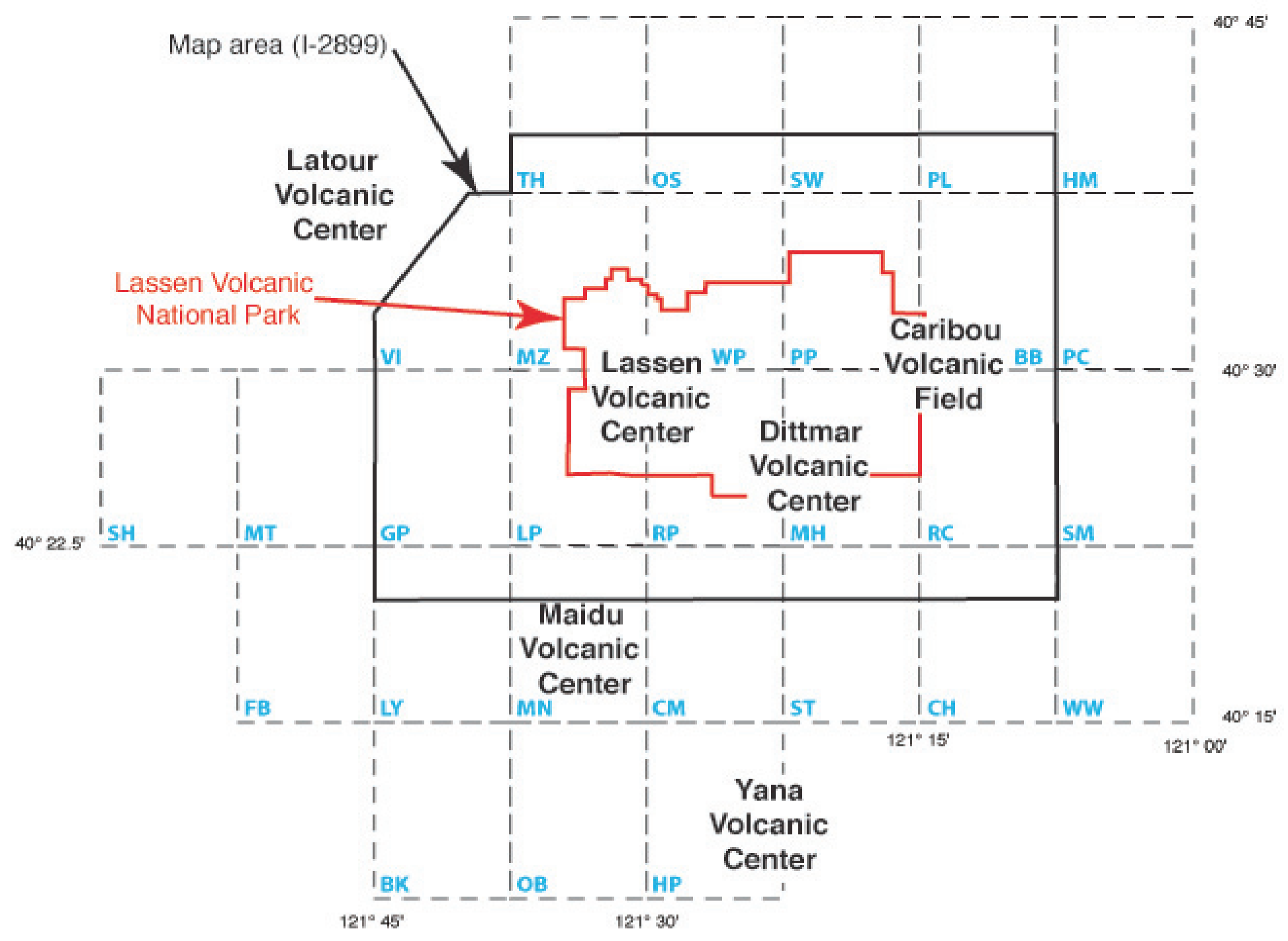

Figure 1. Map showing the location of the Geologic Map of Lassen Volcanic National Park and Vicinity (sheet 1 of Clynne and Muffler, I-2899, in press). Two-letter abbreviations indicate the $71 / 2$ minute quadrangle names (see text) from which samples were collected. The approximate locations of the major volcanic centers are also indicated. 
dispersive X-ray fluorescence analysis of finely ground rock powder (Webb and others, 1990). Precision of the analyses has been determined by repeated analysis of internal standards (Bacon and Druitt, 1988; Clynne, 1993). At the levels present in most Lassen rocks, EDXRF analyses have uncertainties at the $1 \sigma$ level of $2.1 \%$ for $\mathrm{Ba}, 11 \%$ for $\mathrm{Rb}, 0.7 \%$ for $\mathrm{Sr}, 5.3 \%$ for $\mathrm{Y}, 3.1 \%$ for $\mathrm{Zr}$, and $57 \%$ for $\mathrm{Nb}$. See Clynne (1993) for special techniques used to analyze $\mathrm{Rb}$ and discussion of precision for samples with $\mathrm{Rb}<20 \mathrm{ppm}$ and $\mathrm{Nb}<10 \mathrm{ppm}$.

\title{
Location and Attribution of the Samples, Data Processing, and Presentation
}

Rock analyses and sample information are presented in the EXCEL file. The samples are listed in alphanumeric order and the spreadsheet is not write protected so that the user can sort the data set based on location, composition, or rock unit. Column A gives the sample number. Sample prefixes indicate who collected and when the samples were collected: first letter (L) indicates Lassen; second letter indicates collector, primarily Clynne (C) and Muffler (M). Students, field assistants, or collaborators Borg (B), Feeley (F), Keating (K), and Lerch (L) collected a few samples. The number indicates year of collection $(80=1980$, etc.) In column B (CMU Group Code) each sample is correlated with the groups of map units as shown on the Correlation of Map Units diagram for the geologic map (Clynne and Muffler, in press) in order to show stratigraphic and geographic relationships. Abbreviations used are:

\author{
Volcanic Centers \\ Lassen Volcanic Center: \\ LVC-TY Twin Lakes sequence, younger \\ LVC-TO Twin Lakes sequence, older \\ LVC-E Eagle Peak sequence \\ LVC-B Bumpass sequence \\ LVC-BV Brokeoff Volcano \\ LVC-R Rockland caldera complex
}

MVC Maidu Volcanic Center

DVC Dittmar Volcanic Center 
Regional volcanic rocks:

RNW Regional volcanic rocks north and west of Lassen Volcanic Center

RNW-S Sugarloaf chain

RNW-T Tumble Buttes Chain

RSE Regional volcanic rocks south and east of Lassen Volcanic Center

ROC Regional volcanic rocks older than the Caribou Volcanic Field

Caribou Volcanic Field:

CVF-B Bidwell Spring chain

CVF-R Red Cinder chain

CVF-TU Tuya chains

CVF-P Poison Lake chain

CVF-CL Cone Lake sequence

CVF-S Sunrise Peak sequence

CVF-I Island Lake sequence

CVF-C Caribou chain

CVF-BT Beauty Lake chain

The major-element data are presented in weight percent in columns $\mathrm{C}$ through $\mathrm{N}$. Analyses were recalculated to $100 \%$ anhydrous with $\mathrm{Fe}_{2} \mathrm{O}_{3}$ (column E) equal to 0.2 total iron analyzed as $\mathrm{Fe}_{2} \mathrm{O}_{3}$ for all samples except low-potassium olivine basalts (tholeiitic basalts), for which 0.15 was used. Remaining Fe was calculated as FeO (column F) and total Fe, calculated as $\mathrm{FeO}$ is given in column $\mathrm{G}$. Loss on ignition at $900^{\circ} \mathrm{C}$ (LOI) and the total of the original analysis (not including LOI) before recalculation are given in columns $\mathrm{O}$ and $\mathrm{P}$, respectively. $\mathrm{FeOt} / \mathrm{MgO}$ (column Q) was calculated by dividing column $\mathrm{G}$ by $\mathrm{MgO}$ (column $\mathrm{H}$ ) and $\mathrm{Mg \#}$ (column R) was calculated as molar $\left(\mathrm{Mg} / \mathrm{Mg}+\mathrm{Fe}^{+2}\right) 100$.

Trace element abundances in parts per million (ppm) for $\mathrm{Rb}, \mathrm{Sr}, \mathrm{Ba}, \mathrm{Y}, \mathrm{Zr}, \mathrm{Nb}, \mathrm{Ni}, \mathrm{Cr}$, $\mathrm{Cu}$ and $\mathrm{Zn}$ for some samples are presented in columns $\mathrm{S}$ through $\mathrm{AB}$ (left blank on the spreadsheet if not analyzed). 
Samples are correlated to mapped geologic units (map unit symbol, column AC and map unit name, column AD) as given in the Geologic map of Lassen Volcanic National Park and vicinity (Clynne and Muffler, in press). Tholeiitic basalts are indicated by the inclusion of tholeiitic in the unit name. Attribution of some samples to rock units is modified from that given in previous publications and is indicated in the column AE (notes). Samples that are mafic inclusions or have other unusual characteristics are noted in column AE.

Column AF gives the 7 and 1/2 minute quadrangle name from which each sample was collected. Abbreviations used are:

$\begin{array}{lll}\text { BB Bogard Buttes } & \text { MN Mineral } & \text { RP Reading Peak } \\ \text { BK Barkley Mountain } & \text { MZ Manzanita Lake } & \text { SH Shingletown } \\ \text { CH Chester } & \text { MH Mount Harkness } & \text { SM Swain Mountain } \\ \text { CM Childs Meadow } & \text { MT Manton } & \text { ST Stover Mountain } \\ \text { FB Finley Butte } & \text { OB Onion Butte } & \text { SW Swains Hole } \\ \text { GP Grays Peak } & \text { OS Old Station } & \text { TH Thousand Lakes Valley } \\ \text { HM Harvey Mountain } & \text { PL Poison Lake } & \text { VI Viola } \\ \text { HP Humboldt Peak } & \text { PP Prospect Peak } & \text { WP West Prospect Peak } \\ \text { LP Lassen Peak } & \text { PC Pine Creek Valley } & \text { WW Westwood West } \\ \text { LY Lyonsville } & \text { RC Red Cinder } & \end{array}$

Sample locations are given in latitude and longitude both as degrees and decimal minutes (columns AG and $\mathrm{AH}$ ) and as decimal degrees (columns $\mathrm{AI}$ and $\mathrm{AJ}$ ), and are generally accurate to $\sim 10 \mathrm{~m}$. Samples are also electronically located in the ARCINFO map database (Muffler and others, in press) that accompanies the Geologic Map of Lassen Volcanic National Park Clynne and Muffler (in press).

\section{Acknowledgments}

The USGS Geothermal Resources and Volcano Hazards Programs provided funding for this work. Additional analysts for major element WDXRF included J. Baker, A.J. Bartel, J.S. Mee, R.V. Mendes, E. Robb, K. Stewart, and J.S. Wahlberg (all USGS in Lakewood, Colo.). 
Gordon Keating collected LK samples. Reviews of an earlier version of this manuscript by Judy

Fierstein and Julie Donnelley-Nolan improved the presentation and are gratefully acknowledged.

\section{References Cited}

Bacon, C.R., Bruggman, P.E., Christiansen, R.L., Clynne, M.A., Donnelly-Nolan, J.M., and Hildreth, W. 1997, Primitive magmas at five Cascade volcanic fields: melts from hot, heterogeneous sub-arc mantle: Canadian Mineralogist vol. 35, p. 397-423.

Bacon and Druitt, 1988, Compositional evolution of the zoned calcalkaline magma chamber of Mount Mazama, Crater Lake, Oregon: Contributions to Mineralogy and Petrology vol. 98, p. 224-256.

Borg, L.E., 1989, Petrogenesis of Magee composite volcano, northern California: MS thesis, University of Texas at Austin, $128 \mathrm{p}$.

Borg, L.E., 1995, The origin and evolution of magmas from the Lassen region of the southernmost Cascades: Ph.D. dissertation, University of Texas at Austin, 228 p.

Borg, L.E., Blichert-Toft, J., and Clynne, M.A., 2002, Ancient and modern subduction zone contributions to the mantle sources of lavas from the Lassen region of California inferred from Lu-Hf isotopic systematics: Journal of Petrology vol. 43, p. 705-723.

Borg, L.E., Brandon, A.D., Clynne, M.A., and Walker, R.J., 2000, Re-Os isotopic systematics of primitive lavas from the Lassen region of the Cascade arc, California: Earth and Planetary Science Letters vol. 177, p. 301-317.

Borg, L.E and Clynne, M.A., 1998, The petrogenesis of felsic calc-alkaline magmas from the southernmost Cascades, California: Origin by partial melting of basaltic lower crust: Journal of Petrology vol. 39, p. 1197-1222.

Borg, L.E., M.A. Clynne, and Bullen, T.D., 1997, The variable role of slab-derived fluids in the generation of a suite of primitive calc-alkaline lavas from the southernmost Cascade Range: Canadian Mineralogist 35:425-452.

Bullen, T.D., and Clynne, M.A., 1990, Trace element and isotopic constraints on magmatic evolution at Lassen Volcanic Center, California: Journal of Geophysical Research, vol. 95, p. 19,671-19,691.

Clynne, M.A., 1984, Stratigraphy and major-element geochemistry of the Lassen Volcanic Center, California: U.S. Geological Survey Open-File Report 84-224, 168 p.

Clynne, M.A., 1990, Stratigraphic, lithologic and major element geochemical constraints on magmatic evolution at Lassen Volcanic Center, California: Journal of Geophysical Research, vol. 95, p. 19,651-19,669.

Clynne, M.A., 1993, Geologic studies of the Lassen volcanic center, Cascade Range, California: $\mathrm{Ph} . D$. dissertation, University of California- Santa Cruz, $404 \mathrm{p}$.

Clynne, M.A., 1999, Complex magma mixing origin for multiple volcanic lithologies erupted in 1915, from Lassen Peak, California: Journal of Petrology vol. 40, p. 105-132.

Clynne, M.A. and L.J.P. Muffler, in press, Geologic map of Lassen Volcanic National Park and vicinity, California: U.S. Geological Survey Scientific Investigations Map I-2899, scale 1:50,000, 241 p. pamphlet.

Feeley, T.C., Clynne, M.A., Winer, G.S., and Grice, W.A., in press, Oxygen isotope geochemistry of the Lassen Volcanic Center, California: Journal of Petrology.

Lerch, F.G., 1987, Geology of the Red Cinder 7.5-minute quadrangle, Lassen and Plumas Counties, California: MS thesis, Colorado School of Mines $274 \mathrm{p}$. 
Muffler, L.J.P., Clynne, M.A., and Champion, D.E., 1994, Late Quaternary normal faulting of Hat Creek Basalt, northern California: Geological Society of America Bulletin, v. 106, p. 195-200.

Muffler, L.J.P., Robinson, J.E., Felger, T.J., Dutton, D.R., and Clynne, M.A., in press, Database for the Geologic Map of Lassen Volcanic National Park and vicinity, California: U.S. Geological Survey Data Series [CD-ROM].

Rose, T.P., Criss, R.E., Mughannum, A.J., and Clynne, M.A., 1994, Oxygen isotope evidence for hydrothermal alteration within a Quaternary stratovolcano, Lassen Volcanic National Park, California: Journal of Geophysical Research vol. 99, p. 21,621-21,633.

Taggart, J.E. Jr., Lindsey, J.R., Scott, B.A., Vivit, D.V., Bartel, A.J., and Stewart, K.C., 1987, Analysis of geologic materials by wavelength dispersive X-ray florescence spectrometry: U.S. Geological Survey, Bulletin 1770, p. E1-E19.

Trimble, D.A., Clynne, M.A., and Robinson, S.W., 1984, The application of uranium-thorium systematics to rocks from the Lassen dome field, California: U.S. Geological Survey Open-File Report 84-371, 99 p.

Webb, P.C., Potts, P.J., and Watson, J.S., 1990, Trace element analysis of geochemical reference samples by energy dispersive X-ray florescence spectrometry: Geostandards Newsletter vol. 14 , p. 361-372. 